\title{
Perumusan Model Moneter Berdasarkan Perilaku Gas Ideal
}

\author{
Rachmad Resmiyanto \\ Program Studi Pendidikan Fisika, Universitas Ahmad Dahlan, \\ Kampus III, J1. Prof. Dr. Soepomo, SH, Yogyakarta 55164 Indonesia \\ Surat-e: rachmadresmi@uad.ac.id
}

Telah disusun sebuah model moneter yang berdasarkan perilaku gas ideal. Model disusun dengan menggunakan metode kias/analogi. Model moneter gas ideal mengiaskan jumlah uang beredar dengan volume gas, daya beli dengan tekanan gas dan produksi barang dengan suhu gas. Model ini memiliki formulasi yang berbeda dengan Teori Kuantitas Uang (Quantity Theory of Money) yang dicetuskan oleh Irving Fisher, model moneter Marshal-Pigou dari Cambridge serta model moneter ala Keynes. Selama ini 3 model tersebut dianggap sebagai model yang mapan dalam teori moneter pada buku-buku teks ekonomi. Model moneter gas ideal dapat menjadi cara pandang baru terhadap sistem moneter.

Kata kunci: model moneter, gas ideal, teori kuantitas uang, model cambridge, model keynes

\section{Pendahuluan}

Ada banyak sekali aliran dalam ekonomi moneter. Beberapa diantaranya ialah aliran Keynesian, pascaKeynesian, Neo-Keynesian, aliran Klasik, aliran Neo-Klasik, aliran Monetaris, aliran Chicago, aliran Virginia. Juga ada madzhab Austria (Rothbard, 2007, hal. xvi, Pengantar Edisi Indonesia).

Salah satu pemikiran aliran Klasik tentang uang ialah Teori Kuantitas Uang (Quantity Theory of Money) yang diusulkan oleh Irving Fisher (I867-1947). Ia adalah seorang monetaris dari Universitas Yale, Amerika.

\section{Teori Kuantitas Uang}

Teori ini menganggap orang memegang uang untuk membeli barang dan jasa. Hal ini dapat dimengerti sebab orang memegang uang untuk membeli barang dan jasa. Kian banyak uang yang dibutuhkan dalam transaksi, kian banyak pula uang yang hendak dipegang. Jadi jumlah uang dalam perekonomian sangat erat kaitannya dengan jumlah rupiah yang dipertukarkan dalam transaksi. Hubungan antara transaksi dan uang dinyatakan dalam persamaan berikut,

$$
M V=P T
$$

dengan $M$ adalah jumlah uang beredar, $V$ kecepatan perputaran uang (laju uang beredar), $P$ harga barang/jasa dan $T$ merupakan total jumlah transaksi.
Teori ini memberikan inspirasi betapa pentingnya mengendalikan jumlah uang beredar. Pengendalian jumlah uang beredar bertujuan untuk menjamin pertumbuhan output, stabilitas harga dan full employment (Hartono, 2006, hal. 306).

Tetapi, persamaan ini menyimpan masalah, yaitu sulitnya mengukur/menghitung jumlah transaksi (Mankiw, 2007, hal. 83). Untuk memecahkan masalah ini, jumlah transaksi $\mathrm{T}$ diganti dengan keseluruhan output dari perekonomian, yakni Y . Transaksi dan output sangat berkaitan. Makin banyak perekonomian berproduksi, kian banyak barang dibeli dan dijual. Nilai uang dari transaksi sebanding dengan nilai uang dari output.

Output dari perekonomian adalah pendapatan. Dilihat dari sisi produksi, maka pendapatan perekonomian adalah jumlah seluruh barang dan jasa yang dapat dihasilkan. Jumlah ini disebut sebagai Produk Domestik Bruto riil (PDB riil) atau Gross Domestic Product riil (GDP riil). Nilai PDB yang dihitung pada suatu tingkat harga konstan disebut PDB nominal. Perbandingan antara PDB nominal dan PDB riil disebut deflator PDB.

Oleh karena itu, jumlah uang yang beredar dapat dilihat sebagai pendapatan perekonomian. Persamaan baru yang mengakomodasi PDB ini adalah

$$
M V=P Y
$$

Maka $P Y$ adalah PDB nominal, $P$ selain sebagai harga, juga dapat dimaknai sebagai deflator PDB. Persamaan ini juga dapat ditulis dalam bentuk 


$$
M V=\mathrm{PDB}
$$

Persamaan terakhir ini menunjukkan bahwa pertumbuhan ekonomi dapat diramalkan jika terjadi perubahan jumlah uang beredar. Namun, ketepatan ramalan ini masih dipengaruhi oleh kelajuan uang beredar. Laju uang beredar menandakan berapa kali rata-rata rupiah dibelanjakan untuk transaksi dalam selang waktu tertentu (umumnya digunakan selang waktu I tahun).

Hartono (2006, hal. 306-308) menguraikan bahwa aliran monetaris berasumsi nilai $\mathrm{V}$ selalu stabil tiap tahun. Pasalnya, upah dan gaji dibayarkan secara teratur sehingga pola permintaan uang untuk transaksi akan stabil tiap tahunnya. Akibat dari asumsi ini adalah perubahan jumlah uang beredar $\mathrm{M}$ akan langsung mempengaruhi PDB. Logika inilah yang dipakai oleh bank sentral untuk meningkatkan PDB. Praktiknya, kenaikan jumlah uang beredar $M$ memiliki 3 kemungkinan akibat, yaitu (I) harga $\mathrm{P}$ naik tanpa diikuti kenaikan PDB riil Y, (2) PDB riil Y naik tanpa diikuti kenaikan harga $P$, (3) campuran antara kenaikan harga $\mathrm{P}$ dan $\mathrm{PDB}$ riil $\mathrm{Y}$.

Aliran monetaris meramalkan bahwa apabila perekonomian telah mencapai full employment maka peningkatan jumlah uang beredar akan mengakibatkan harga-harga turut naik dan tidak ada kenaikan output. Inilah alternatif (I) tadi. Fenomena ini disebut inflasi.

Apabila perekonomian sedang resesi, maka naiknya jumlah uang beredar akan mengakibatkan naiknya output tanpa ada kenaikan harga. Ini adalah alternatif (2). Alternatif (3) akan terjadi manakala perekonomian mendekati kondisi full employment dan ada kenaikan jumlah uang beredar.

Menurut Mankiw (2007, hal. 85), teori kuantitas uang ini memberikan penjelasan apa yang terjadi ketika bank sentral mengubah jumlah uang beredar. Teori kuantitas uang menyatakan bahwa tingkat harga sebanding dengan jumlah uang beredar. Karena inflasi merupakan perubahan persentase tingkat harga maka teori kuantitas uang juga merupakan teori inflasi. Boediono (2010, hal. 167-I76) menguraikan bahwa ada 3 kelompok teori inflasi, yaitu teori kuantitas uang, teori Keynes dan teori strukturalis.

Sisi lain dari tingkat harga barang dan jasa dilihat dari perspektif uang adalah daya beli uang (purchasing power). Artinya dengan sejumlah uang tertentu akan didapat barang yang lebih banyak jika harga turun dan hanya mendapatkan barang sedikit jika harga naik. Karena itu, daya beli uang berbanding terbalik dengan harga,

$$
N=\frac{1}{P}
$$

Dalam mengaitkan teori kuantitas uang, fenomena inflasi dan peran bank sentral, Mankiw (2007, hal. 85) menulis,

"Jadi, teori kuantitas uang menyatakan bahwa bank sentral, yang mengawasi jumlah uang beredar, memiliki kendali tertinggi atas tingkat inflasi. Jika bank sentral mempertahankan jumlah uang beredar tetap stabil, tingkat harga akan stabil. Jika bank sentral meningkatkan jumlah uang beredar dengan cepat, tingkat harga akan meningkat dengan cepat."

Kaitan antara teori kuantitas uang dan inflasi juga ditegaskan oleh Milton Friedman. Ia pernah menerima nobel ilmu ekonomi pada tahun 1976. Menurutnya, inflasi selalu dan di mana pun merupakan fenomena moneter. Teori kuantitas uang mengarahkan siapapun untuk sepakat bahwa pertumbuhan jumlah uang adalah determinan penting dalam tingkat inflasi (Mankiw, 2007, hal. 86).

Teori kuantitas uang merupakan teori penting dalam makroekonomi. Menurut Bank Indonesia (BI), perkembangan makroekonomi suatu negara ditunjukkan oleh 4 indikator utama yaitu PDB per kapita, tingkat harga, laju peredaran uang, dan suku bunga BI (http://www.bi.go.id). Jadi 3 indikator utama termaktub dalam persamaan teori kuantitas uang.

\section{Madzhab Cambridge}

Pada saat yang hampir bersamaan, Marshal dan Pigou dari Universitas Cambridge juga mengembangkan perumusan permintaan uang. Rumusan Cambridge ialah

$$
M=k P Y, \quad k=\frac{1}{V}
$$

Secara matematis, rumusan Cambridge sama dengan rumusan Fisher, namun keduanya memiliki filosofi yang berbeda. Marshall-Pigou menyatakan bahwa $k$ merupakan tingkat keinginan seseorang untuk menyimpan sebagian kekayaannya. Dengan demikian konsep Cambridge memandang uang ialah sebagai konsep stok. Ini membedakan dengan konsep uang dalam teori kuantitas uang, yakni sebagai konsep aliran (Karim, 2008, hal. I8II82).

\section{Model Keynes}

Konsep ini berbeda dengan konsep Keynes yang mulai mengaitkan peran bunga uang (riba). Mulanya, ia berasumsi bahwa aliran uang di masyarakat akan dipengaruhi 3 motif yakni transaksi, berjaga-jaga dan spekulasi. Konsep Keynes dapat ditulis sebagai

$$
M=[k Y+\phi(r, w)] P,
$$


dengan lambang $\phi(r, W)$ menyatakan motif spekulasi yang dinyatakan sebagai fungsi dari tingkat suku bunga yang berlaku $r$ dan nilai riil dari kekayaan yang ada di masyarakat (Boediono, 20I0, hal. 35-38).

Setelah Keynes, beberapa teori tentang uang juga selalu mengaitkan dengan tingkat suku bunga. Misalnya teori Baumol-Toubin dan teorinya Friedman. Pustaka yang mengupas ini lebih rinci diantaranya ialah Boediono (2010, hal. 39-73).

\section{Pandangan Fisikawan tentang Uang}

V. Z. Nuri (2002) menulis sebuah makalah ekonofisika tentang inflasi dengan mengulik topik uang dan perbankan. Judul makalahnya, Fractional Reserve Banking as Economic Parasitism: A Scientific, Mathematical, \& Historical Expose, Critique and Manifesto. Dalam makalah itu ia berangkat dari persamaan Irving Fisher $M V=P Y$. Persamaan ini kemudian dikiaskan dengan persamaan gas ideal $p v=$ $n R T$. Dalam perumusannya, ia berkias

$$
\begin{aligned}
\frac{1}{P} & \Leftrightarrow p \\
M V & \Leftrightarrow v \\
Y & \Leftrightarrow T
\end{aligned}
$$

Dengan persamaan gas ideal ia menunjukkan bahwa inflasi merupakan konsekuensi dari meningkatnya pasokan uang. Dalam telisik sepanjang 60 halaman itu ia berkesimpulan sistem perbankan cadangan pecahan (FRB) sebagai parasit perekonomian yang dilakukan oleh kartel perbankan swasta. Meskipun menggunakan metafora gas ideal, makalah Nuri lebih banyak membahas perbankan secara teoretik dan kualitatif. Ia juga tidak menyuguhkan bukti data-data yang mendukung kesimpulannya.

Model perekonomian dengan termodinamika yang lebih lengkap dibangun oleh Bryant (20I2) melalui bukunya Thermoeconomics: A Thermodynamics Approach to Economics. Dalam bab 5 tentang uang, ia juga menggunakan kias gas ideal seperti V.Z. Nuri (2002) tetapi perpadanan antar besarannya berbeda.

Dalam kiasnya, Bryant memodelkan persamaan gas ideal $P V=N k T$ setara dengan persamaan kuantitas uang $M V=P Y$. Rinciannya ialah

$$
\begin{aligned}
P & \Leftrightarrow P \text { (tingkat harga) } \\
V & \Leftrightarrow Y \text { (volume output) } \\
N k & \Leftrightarrow M \text { (jumlah uang) } \\
T & \Leftrightarrow V \text { (indeks perdagangan) }
\end{aligned}
$$

Yang dimaksud indeks perdagangan ialah kecepatan sirkulasi uang.

Untuk besaran $N k$, terdiri dari $N$ sebagai jumlah instrumen mata uang dalam peredaran dan $k$ nominal uang yang berlaku misalnya $\$ I$, Rp I dan sebagainya.

\section{Gas Ideal}

Gas ideal adalah gas hipotetis (gas khayalan) yang model molekulernya mengikuti asumsi tertentu. Pertama, gas terdiri dari partikel-partikel, yang dinamakan molekulmolekul. Bergantung pada gas tersebut, maka setiap atom akan terdiri dari sebuah atom atau sekelompok atom. Jika gas tersebut adalah sebuah elemen atau suatu persenyawaan dan berada di dalam suatu keadaan stabil, maka semua molekul akan ditinjau sebagai molekul yang identik.

Kedua, molekul-molekul bergerak secara acak dan menuruti hukum-hukum gerak Newton. Molekul-molekul bergerak di dalam semua arah dan dengan berbagai laju. Pada waktu kapanpun, beberapa persen molekul bergerak dengan kelajuan tinggi, dan beberapa persen lainnya bergerak dengan kelajuan rendah.

Ketiga, jumlah seluruh adalah besar. Arah dan laju gerakan dari setiap molekul dapat berubah secara tiba-tiba karena tumbukan dengan dinding atau dengan molekul lain. Jumlah besar tumbukan yang dihasilkan akan mempertahankan distribusi kecepatan molekuler secara keseluruhan dan keacakan gerakan.

Keempat, volume molekul-molekul adalah pecahan kecil yang dapat diabaikan dari volume yang ditempati oleh gas tersebut.

Kelima, tidak ada gaya-gaya yang cukup besar yang beraksi pada molekul-molekul kecuali selama tumbukan. Sampai taraf dimana anggapan ini benar maka sebuah molekul akan bergerak dengan kecepatan seragam diantara tumbukantumbukan. Karena molekul mempunyai ukuran kecil, maka jarak rata-rata di antara molekul-molekul adalah besar dibandingkan terhadap ukuran sebuah molekul. Maka, jangkauan pengaruh gaya-gaya molekuler tersebut dapat disamakan dengan ukuran molekuler.

Keenam, tumbukan-tumbukan adalah elastik dan tumbukan-tumbukan terjadi dalam waktu yang sangat singkat. Konsep gas ideal sangat bermanfaat sebab gas-gas nyata pada tekanan yang sangat rendah (di bawah tekanan kritis) dan pada suhu tinggi (di atas suhu kritis) memiliki sifat seperti gas ideal.

Persaman keadaan gas ideal dinyatakan sebagai

$$
P V=n R T
$$


dengan $P$ tekanan gas ideal (N), $V$ volume gas ideal (m3), $n$ jumlah mol gas ideal, $R$ tetapan universal gas ideal yakni sebesar 8.3 I4,3 $\mathrm{J} \mathrm{Kmol}^{-1} \mathrm{~K}^{-1}$, $T$ suhu gas $(\mathrm{K})$.

Gas ideal dapat mengalami beragam proses sesuai dengan keadaan besaranbesarannya. Proses ini sering disebut sebagai proses termodinamika, yakni proses dengan volume tetap (isokhorik), tekanan tetap (isobarik), suhu tetap (isotermik) dan proses adiabatik. Sebenarnya, proses-proses ini merupakan manifestasi dari ekspansi dan kompresi gas ideal. Hukum umum ekspansi dan kompresi gas ideal menyatakan bahwa

$$
P V^{n}=\text { tetap }
$$

Persamaan ini memberikan hubungan antara tekanan dan volume gas. Nilai $n$ tergantung pada keadaan alami gas dan perubahan keadaan ekspansi atau kompresi terjadi. Nilai $n$ membentang dari nol sampai tak berhingga, $0 \leq n \leq \infty$.

Proses untuk beragam nilai $n$ yang istimewa dapat dirinci sebagai berikut:

I. Jika $\mathrm{n}=0$, maka $P V^{0}=$ tetap. Ini artinya $\mathrm{P}$ tetap.

Proses ini juga disebut isobarik,

2. Jika $\mathrm{n}=\mathrm{I}$, maka $P V^{1}=$ tetap. Ini artinya PV tetap.

Proses ini juga disebut isotermik,

3. Jika n $=\gamma$ maka $P V^{\gamma}=$ tetap. Proses ini juga

disebut proses adiabatik,

4. Jika $\mathrm{n}=\infty$, maka $P V^{\infty}=$ tetap. Ini artinya $V$ tetap.

Proses ini juga disebut isokhorik.

Grafik yang menggambarkan proses-proses ini diringkas dalam gambar

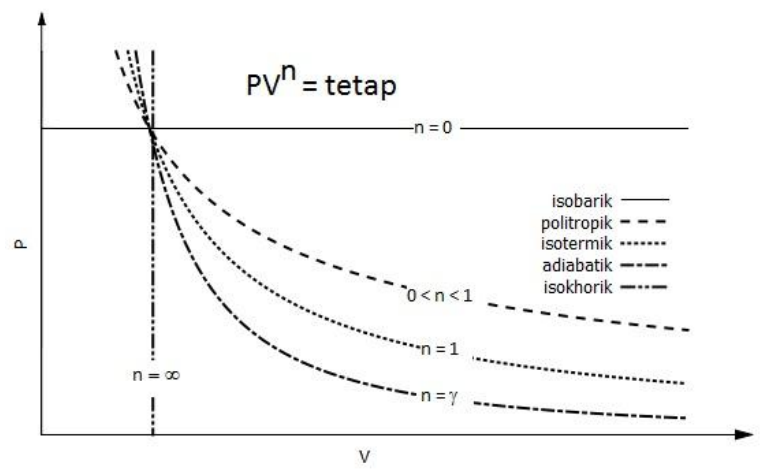

Gambar I Proses gas ideal $P V^{n}=$ tetap untuk berbagai nilai $n$

\section{Proses Barter}

Awalnya, kegiatan niaga dilakukan tanpa melibatkan uang. Untuk memenuhi kebutuhannya, manusia melakukan proses pertukaran barang dengan barang. Sistem tukar-menukar ini biasa disebut sebagai barter. Jadi, seorang penenun kain yang memerlukan beras ia harus menukarkan kainnya kepada petani yang memiliki beras. Demikian juga nelayan yang memiliki ikan harus menukarkan ikannya dengan beras ketika ia membutuhkan beras. Semua barang ditukar dengan barang yang lain.

Setelah melalui proses pertukaran yang panjang, akhirnya orang akan menemukan bahwa setiap barang ternyata memiliki nilai perbandingan tertentu dengan barang yang lain. Perbandingan tiap barang akhirnya bernilai unik. Misalnya antara beras dengan pakaian. Sekian takar beras dapat ditukar dengan sekian potong pakaian. Proses ini dapat dinyatakan dalam sebuah persamaan matematika sederhana,

$$
\alpha x \text { beras }=\beta x \text { pakaian }
$$

atau

$$
\frac{\alpha}{\beta}=\frac{\text { pakaian }}{\text { beras }}
$$

dengan lambang $\alpha$ menyatakan daya tukar beras terhadap pakaian dan $\beta$ menyatakan daya tukar pakaian terhadap beras. Daya tukar $\alpha$ dan $\beta$ adalah sifat intrinsik dan melekat dalam barang. Dengan cara yang sama, setiap barang akan memiliki nisbah yang unik terhadap barang lainnya.

Dengan demikian, secara umum sistem pertukaran ini dapat ditulis sebagai

$$
\text { barang A } \mathrm{x} \text { daya tukar= barang } \mathrm{B}
$$

Namun demikian, sistem barter ini memiliki kesulitan sebab barter hanya dapat terjadi ketika ada 2 orang yang sama-sama membutuhkan barang yang sebaliknya. Seorang yang memiliki pakaian dan hendak menukarnya dengan beras maka ia harus menemukan orang yang memiliki beras dan juga hendak menukarnya dengan pakaian. Jadi, harus ada kebetulan ganda.

\section{Proses Jual Beli}

Untuk mengatasi kesulitan-kesulitan dalam proses barter diperlukan satu barang universal yang dapat diterima oleh setiap pemilik barang. Barang universal ini adalah alat tukar, dikenal sebagai uang. Dengan adanya uang, sistem pertukaran tidak lagi langsung barang ke barang, tetapi menjadi pertukaran tak langsung, barang ke uang ke barang. 
Kehadiran uang memberi manfaat besar. Rothbard (2007, hal. 7) menyatakan bahwa uang merupakan instrumen mengagumkan yang telah memungkinkan berkembangnya peradaban. Setelah pertukaran dilakukan dengan uang, semua nisbah-tukar dinyatakan dalam uang. Dengan demikian, sekarang orang dapat membandingkan nilai pasar setiap barang dengan nilai pasar barang lain. Nisbah-tukar inilah yang disebut sebagai harga. Uang bekerja sebagai denominator umum untuk semua harga barang. Perlu ditegaskan bahwa uang tidak mengukur harga atau nilai, hanya berfungsi sebagai denominator umum dalam pernyataan harga. Singkatnya, harga dinyatakan dalam uang tetapi tidak diukur dengan uang (Rothbard, 2007, hal. I0-I I).

Transaksi antara barang-uang dan uang-barang disebut sebagai transaksi jual beli. Maka, uang sebagai alat tukar memiliki sifat intrinsik yaitu daya beli. Sejumlah uang dapat dibelanjakan untuk mendapatkan beras. Sejumlah uang yang lebih banyak dapat dibelanjakan untuk mendapatkan jumlah beras yang lebih banyak. Uang memiliki sifat daya beli.

Transaksi antara uang dengan sifat daya belinya yang ditukar dengan barang dapat dirumuskan sebagai

$$
\text { barang } \mathrm{x} \text { harga }=\text { uang. }
$$

Dengan mengingat kembali bahwa I/harga ialah daya beli maka didapatkan persamaan baru

$$
\text { uang } \mathrm{x} \text { daya beli }=\text { barang. }
$$

Persamaan ini menunjukkan hubungan antara uang dan daya beli yang memiliki sifat berbanding terbalik. Untuk jumlah barang yang tetap, jika jumlah uang meningkat maka daya beli menurun. Sebaliknya, jika jumlah uang menurun maka daya beli meningkat.

\section{Kias Gas Ideal}

Daya beli uang merupakan kekuatan intrinsik uang. Maka, uang dengan daya belinya adalah sebuah tenaga.

Barang-barang transaksi diproduksi oleh manusia untuk memenuhi kebutuhan hidupnya. Keseluruhan barang-barang (dan jasa) ini jika dilihat dari perspektif yang lebih besar, misalnya negara, merupakan pendapatan nasional atau Produk Domestik Bruto (PDB). Secara individu, produksi barang/jasa dapat berbeda-beda, dapat lebih banyak atau lebih sedikit. Konsep pendapatan nasional memandang produksi barang/jasa ini secara keseluruhan.

Mankiw (2007, hal. I7) menyatakan bahwa PDB dapat dipandang sebagai pengeluaran total atas output barang dan jasa perekonomian. Kaitannya dengan uang, Mankiw (2007, hal. I9) menegaskan bahwa PDB adalah nilai pasar semua barang dan jasa akhir yang diproduksi dalam perekonomian selama kurun waktu tertentu.

Dengan demikian, dapat dibuat persamaan baru yaitu

$$
\text { uang } \mathrm{x} \text { daya beli }=\text { barang }=\mathrm{PDB} \text {. }
$$

Persamaan ini menyuguhkan makna bahwa jumlah uang yang beredar di suatu negara setara dengan PDB negara tersebut. Tiap satuan uang dalam uang beredar itu masing-masing memiliki daya belinya sendiri. Daya beli ini menyatakan kekuatan tiap satuan uang jika ditukar dengan barang. Oleh karena itu, dari sini dapat dipahami dengan mudah ketika Mankiw (2007, hal. I9) menyatakan PDB mungkin merupakan variabel aliran paling penting dalam perekonomian.

Dalam fisika, sejumlah gas yang menempati ruang dengan volume $V$ memiliki sifat intrinsik yaitu tekanan $P$ dengan nilai tertentu. Jika volume gas kian besar maka kepadatan molekul gas menjadi renggang sehingga tekanan gas kian kecil. Sebaliknya, jika volume gas semakin kecil maka tekanan gas semakin besar. Volume gas berbanding terbalik dengan tekanan. Ini dikenal sebagai hukum Boyle.

Selain tekanan, sejumlah gas dengan volume $V$ juga memiliki sifat intrinsik suhu T. Dari segi pandang molekuler, T merupakan atribut molekul secara keseluruhan yakni berbanding lurus dengan energi kinetik rata-rata. Secara individu, energi kinetik molekul dapat lebih tinggi atau lebih rendah. Berdasarkan eksperimen, ketika tekanan dibuat konstan, volume gas berbanding lurus terhadap suhu gas. Ini adalah hukum Charles dan Gay-Lussac.

Hubungan antara $\mathrm{P}, \mathrm{V}$ dan $\mathrm{T}$ dinyatakan sebagai $\mathrm{PV} \approx \mathrm{T}$. Untuk gas ideal dinyatakan dengan persamaan

$$
P V=n R T
$$

dengan $n$ jumlah mol gas ideal, $R$ tetapan universal gas ideal yakni sebesar 8.3 I4,3 J/(Kmol K).

Sejumlah uang beredar di suatu negara dengan sifat daya belinya analog dengan gas bervolume $V$ dengan sifat tekanannya. Barang dan jasa yang dihasilkan yakni PDB analog dengan sifat intrinsik gas yang lain yaitu suhu $T$.

Dalam analogi ini, jumlah uang bersesuaian dengan volume gas. Kekuatan uang, yakni daya belinya, bersesuaian dengan tekanan gas. Sementara PDB yang merupakan cara pandang makro terhadap produksi barang dan jasa tiap individu bersesuaian dengan suhu yang juga merupakan cara pandang makro terhadap aktivitas kinetik molekul-molekul gas. Ini dapat ditulis,

$$
\begin{gathered}
P=\text { daya beli uang } \\
V=\text { jumlah uang beredar } \\
T=\text { PDB. }
\end{gathered}
$$

Karena bilangan $n$ dan $R$ merupakan tetapan gas ideal yang didapat dari percobaan, maka kebutuhan terhadap bilangan ini untuk sementara belum diperlukan. Umumnya data-data moneter yang ada tidak pernah menyajikan daya beli tetapi harga barangbarang. Harga barang-barang ini biasa dinyatakan dalam bentuk indeks, dikenal sebagai indeks harga konsumen (IHK). Mekanisme teknis penentuan IHK dapat dilihat dalam beberapa pustaka seperti Rosyidi (20II, hal. I28-I3I), Hartono (2006, hal. 316-3I7) atau laman Badan Pusat Statistik, http://www.bps.go.id. Maka, daya beli pun juga dinyatakan dengan indeks, yaitu I/IHK. Daya beli dan harga konsumen tidak 
bersatuan mata uang sebab ia dinyatakan dalam indeks. Jumlah uang beredar dan PDB dinyatakan dalam satuan mata uang.

Dengan demikian sekarang kita dapat menyusun persamaan moneter gas ideal sebagai

$$
P V=T
$$

dengan besaran-besarannya

$$
\begin{gathered}
\text { [indeks, tanpa satuan }][\text { satuan mata uang }]=[\text { satuan mata } \\
\text { uang }],
\end{gathered}
$$

atau jika $T$ tidak dinominalkan dengan harga pasar maka $T$ merupakan barang sehingga

$$
[\text { satuan mata uang }]^{-1}[\text { satuan mata uang }]=[\text { barang }] \text {. }
$$

Persamaan moneter gas ideal memiliki makna bahwa stok uang setara dengan jumlah barang. Ini berbeda dengan konsep teori kuantitas uang Fisher yang menyatakan bahwa konsep uang merupakan aliran. Meskipun makna persamaan ini dekat dengan madzhab Cambride tetapi persamaan moneter gas ideal melibatkan unsur daya beli uang atau harga barang. Dalam madzhab Cambridge, konsep uang sebagai stok dinyatakan oleh besaran aliran kecepatan uang yang dianggap tetap. Persamaan moneter gas ideal sejatinya juga menyatakan bahwa uang merupakan aliran, suatu saat ia dapat menjadi alat tukar dan pada saat yang lain ia menjadi barang, sebagai konsep gas ideal sebagai zat alir yang mudah mengalir ke ruang mana saja.

Untuk menelisik bagaimana perilaku uang sebagaimana perilaku gas ideal, maka diperlukan data-data harga, jumlah uang beredar dan PDB negara. Data-data ini kemudian dapat diplot dalam diagram $P V$ sebagaimana perilaku gas ideal yang dapat diplot dalam diagram $P V$. Dari plot itu dapat disimpulkan bagaimana perilaku uang dalam sistem moneter kita.

\section{Kesimpulan}

Proses moneter dapat dikiaskan dengan proses gas ideal. Dalam kias ini, tekanan gas dikiaskan sebagai daya beli uang, volume gas dikiaskan sebagai jumlah uang beredar dan suhu gas dikiaskan sebagai PDB. Perilaku uang baru dapat ditelisik setelah didapatkan data harga barang, jumlah uang beredar dan PDB. Persamaan moneter gas ideal dapat sejajarkan dengan persamaan kuantitas uang Irving Fisher, madzhab Cambridge dan juga Keynes.

\section{Kepustakaan}

Boediono, 2010, Ekonomi Moneter: Seri Sinopsis Pengantar Ilmu ekonomi No. 5, Ed.3, Cet.I4, BPFEYogyakarta, Yogyakarta

Bryant, John, 2012, Thermoeconomics: A Thermodynamic Approach toEconomics, Third edition ed., Economic Consultancy, Vocat International, http://EconPapers.repec.org/RePEc:voc:vibook:tebp20 I2.

Hartono, Toni, 2006, Mekanisme Ekonomi: dalam Konteks Ekonomi Indonesia, Cet.I, Remaja Rosdakarya, Bandung.

Karim, Adiwarman A., 2008, Ekonomi Makro Islami, Ed.I, Cet.2, Raja Grafindo Persada, Jakarta.

Mankiw, N. Gregory, 2007, Makroekonomi, Ed.6, Cet.I, Erlangga, Jakarta.

Rosyidi, Suherman, 20II, Pengantar Teori Ekonomi: Pendekatan kepada TeoriEkonomi Mikro dan Makro, Ed.9, Cet.9, Rajawali Pers, Jakarta.

Rothbard, Murray N., 2007, Apa yang Dilakukan Pemerintah terhadap Uang Kita?: sebuah pengantar komprehensif ekonomi uang dari madzhab Austria, Granit, Jakarta

V. Z. Nuri, 2002, Fractional Reserve Banking as Economic Parasitism: A Scientific, Mathematical \& Historical Expose, Critique, and Manifesto, Macroeconomics, EconWPA, http://EconPapers.repec.org/RePEc:wpa:wuwpma:020 3005 . 